\title{
Analysis of the Influence of Gender on the Choice of Bank in Southeast Nigeria
}

\author{
Steve Ukenna (Corresponding author) \\ Marketing Unit, Department of Business Management \\ Godfrey Okoye University \\ Ugwuomu-Nike, P.M.B 01014, Enugu State, Nigeria \\ Tel: 234-806-920-5016_E-mail: stephenukenna@yahoo.com \\ Ogechukwu G. Monanu \\ Business Management Unit, Department of Business Management \\ Godfrey Okoye University \\ Ugwuomu-Nike, P.M.B 01014, Enugu State, Nigeria
}

Tel: 234-803-319-9604

Received: September 5, 2011

doi:10.5539/ijbm.v7n3p230
Accepted: November 21, 2011

Published: February 1, 2012

URL: http://dx.doi.org/10.5539/ijbm.v7n3p230

\begin{abstract}
This study sought to empirically identify and rank the important factors considered by southeast male and female bank customers in bank selection in Nigeria. A sample size of 368 bank customers was drawn from Enugu and Onitsha, major commercial cities in southeast Nigeria. Major findings of this study are the six principal factors: a feeling of security, speedy and efficient service, financial benefit, convenient location, availability of ATM, marketing promotion and people influence. Statistical differences between the two genders were found for four factors. This study recommends that banks operating in the southeast should treat male and female genders as distinct market segments when crafting marketing strategies aimed at attracting them and emphasis should be on those factors that the potential bank customer considers most important. This study concludes that time is ripe for banks in southeast Nigeria to start treating male and female genders as distinct market segments.
\end{abstract}

Keywords: Choice, Bank services, Gender, Southeast, Nigeria

\section{Introduction}

Traditionally, women in Nigeria are predominantly house-wives. They are usually not allowed by their husbands to take-up any form of formal employment outside the home; hence their role includes house-keeping and farming for the benefit of the family. Consequently, financial decisions are solely vested with the man or, at best, financial decisions are jointly made. Thus the choice of bank is traditionally vested with the man. This traditional practice tends to be the basis upon which banks design their marketing strategies, wherein no effort is made to consider the male and female gender as distinct market segments.

Partly encouraged by the National Gender Policy, the traditional practice is rapidly phasing out. For instance, more women are acquiring formal education; taking up paid employment; occupying key positions both in corporate and government establishments; and now, most men allow their wives to get paid employment away from the home.

Increasingly, women are becoming powerful income earners. According to the Nigeria Demographic and Health Survey (NDHS) (2008), the proportion of employed women increases steadily with age from 43 percent among age 45-49. A higher proportion of married women than married men were paid in cash only (71 versus 56 percent respectively). NDHS (2008) also reported that "two-third of women (66 percent) now decide for themselves how their earnings are used. On the other hand, 19 percent of women make joint-decisions with their husbands, while 13 percent report that decisions regarding their earnings are mainly made by their husbands." Given these statistics, indeed women are increasingly becoming key financial decision-makers, a situation that 
seems to give them the right of choice of bank.

In the light of the foregoing, it can be deduced that time may be ripe for banks to consider the male and female genders as distinct market segments in designing their marketing strategies.

\subsection{Need for the study}

Three reasons make the present study very urgent. First, the study of Omar and Orakwue (2006), which is the only study the present author was able to access on the subject, used sample respondents in Abuja, hence the result therefrom may not hold true for southeast bank customers due to the differences in the financial responsibility of men and women within a household in the southeast, the perception and choice of banks are likely to vary significantly between men and women in the zone. Second, the study of Omar and Orakwue was carried out in 2003 before the Soludo's banking reforms which was a watershed in Nigeria's banking landscape that changed the banking behaviour of Nigerians, hence a fresh study of bank choice criteria in a post-consolidation era is most necessary. Third, because most banks and other financial service providers tend to design a single marketing program for both genders, it has not been known if the time is ripe to design different market programs for each gender segment or to treat each gender as different market segment.

In addition to the foregoing three reasons that make this study imperative, it is therefore expected to be of benefit to a number of group of people. To bank management, this study provides deeper insight, particularly whether or not to consider gender when designing marketing strategies aimed at attracting and retaining new bank customers. To scholars, this study will further contribute meaningfully to bank marketing literature, thereby constituting an invaluable source of reference for those wishing to embark on similar study.

\subsection{Objectives of the study}

On the strength of the foregoing, the present study is set to pursue the following objectives:

(i) To determine the factors considered important by southeast bank customers in bank selection;

(ii) To determine if there are differences in the factors used by men and women in bank choice decision in southeast.

(iii) To find out if banks consider gender characteristics when crafting their marketing strategies.

\section{Literature Review}

An avalanche of studies has been executed in the domain of bank selection criteria and they are mostly country-specific. For example, Kaufman (1967), Reed (1972), Mason and Mayer (1974), Fitts (1975), Riggall (1980), and Javalgi et al (1989) are earlier studies conducted in the United States. Recent studies carried out in the United States include Boyd et al (1994), Yue and Tom (1995), and Coyle (1999); while Laroche et al (1986) and Kaynak (1986) are examples of studies conducted in Canada. A number of studies conducted in Europe also dominated literature: Holstius and Kaynak (1995) in Finland; Kaynak et al. (1991) in Turkey; Mylonakis et al (1998) in Greece; Lewis (1982) in the UK and Martenson (2007) in Sweden. Some studies have also been conducted in Asia: for example, Ma et al (1996), Gerrard and Cunningham (1997), and Tan and Chua (1986) in Singapore; Haron et al (1994), and Sudin-Haron et al (1994) in Malaysia; Kaynak and Kucukemirogly (1992) in Hong Kong and Erol et al. (1990) in Jordan. A number of studies have also been conducted in the African context: for example, Hinson et al (2009), Narteh and Owusu-Frimpong (2010) in Ghana; Albert, Njanike, and Mukucha (2011) in Zimbabwe; and Omar and Orakwe (1995) and Nkamnebe and Ukenna (2011) in Nigeria.

A close study of the existing literature shows that the common thread among most previous studies is that of analyzing bank choice criteria on the basis of demographic factors. Mokhlis et al (2010) in their study reported that the first major study of note that used demographic factors in analysing bank choice is Laroche et al. (1986), wherein they found that there are some significant differences in choice criteria for retail banks in Canada with respect to gender, language, age, income and educational level groups. In their study in Turkey, Kaynak et al. (1991) reported differences in bank selection criteria based on gender, age and education background of bank customers. In a study in Bangladesh by Rashid and Hassan (2009), they found that customers with different demographic backgrounds reported different levels of importance towards choice criteria for Islamic banks. The study by Omar and Orakwe (2008) cited in Mokhlis et al (2010) investigated gender differences in the relative importance of bank choice criteria in Nigeria. Similarly, Srivatsa and Srinivasan (2008) also investigated gender differences in the relative importance of bank choice criteria in India. Interestingly, the study of Omar and Orakwe (2008) and Srivatsa and Srinivasan (2008) as reported in Mokhlis et al (2010) found some differences in choice factors used by male and female customers in selecting a retail bank for patronage. 
Some of the greatest gender differences in financial behaviour occur in the purchase of long-term investments, such as insurance policies, unit trusts and pensions (Devlin 2002). In the USA, Philp, et al. (1992) note that women were more conservative investors than men, were less willing to commit their savings over long periods of time, and were less likely than men to purchase investments which have a highly variable rate of return. Women were also found to differ from men in their reasons for saving and investing (Hisrich and Ozturk, 1999), their patterns of ownership of financial assets (Woodward and Ozbiligin, 1999), and their use of financial planners (Devlin, 2002). In terms of bank choice criteria, Devlin (2002) found that women were significantly more likely to choose a bank that will provide them with a mortgage and will similarly choose a mortgage where they have another account, indicative of greater concurrent behavioural loyalty on the part of women. Women are also significantly less likely than men to choose a mortgage primarily on the basis of professional advice (Ford and Jones, 2001). All these point to the fact that financial planning decisions have important implications for the financial well-being of women than for men in their retirement years.

A few Nigerian studies have examined bank choice using gender. An earlier study by Agu (1992) argued that the women's market in Nigeria is largely untapped by the banking industry because of the relatively lower income of female workers. He further sustained that although, on average, women's earnings are less than that of their male counterparts, with the increase of college-educated women, that gap is closing. Some of the differences between men and women have been attributed to role perceptions (Alsop, 1984). In relation to the Nigerian environment, two orientations could be used to describe these role differences: traditional, where the husband assumes responsibility for providing for the family and making banking and/or financial decisions; and modern, where both husband and wife share responsibilities of work and financial decision making (Omar and Orakwe, 2006). Muldoon (1989) noted that most men and women in financial environments prefer the modern orientation. As a result of the changing economic situation which is altering the existing financial behaviour, traditional orientation is gradually phasing out in Nigeria.

Various empirical research using different methodologies and approaches have been applied in various parts of the world to examine the criteria that motivate male and female customers in selecting their bank. In their research in Singapore, Tan and Chua (1986) found that advice of friends; neighbours and family members have a stronger influence on customers' decisions, compared with other variables in selecting financial institutions. This finding is consistent with the ethos of Nigerian culture that emphasises social and family ties. Also Haron et al, (1994) reported that 'safety of one's funds' to be the main criterion followed by 'paying highest interest rates on savings', 'location', 'reputation', 'availability of loans', 'low interest rates on loans', 'ease of qualifying for current account by maintaining a minimum balance and, lastly, 'Saturday banking'. The present author was able to access a study conducted in Nigeria by Omar and Orakwe (2006) involving 246 respondents drawn from Abuja. In their study, they found that men considered safety of funds, efficient service and speed of transaction most important in their bank selection; while women considered speed of transaction, safety of funds, and recommendation by relatives/friends as most important in bank selection. The limitations of the study of Omar and Orakwue (2006) that were stated in section 1.1 above have partly reinforced the need for the present study.

\section{Research Methodology}

\subsection{Instrument: Design and Testing}

A structured questionnaire was designed for this study. The questionnaire was divided into two sections, namely: Section A and Section B. Section A sought to collect bio-data of respondents. Options were provided for each question and the respondents were expected to tick in the box that applies. Section B dealt with the core-subject matter. We listed 38 bank attributes that influence bank choice which were particularly drawn from the works of Mokhlis (2009), Narteh and Owusu-Frimpong (2010), Gerrard and Cunningham (2001) and Omar and Orakwue (2006). The respondents were asked, "To what extent are the following 36 factors important in your choice of a bank to open an account with?" The 36 factors were measured on a five point Likert-type scale of importance ranging from 1 rated as "not important at all" to 5 rated as "very important".

The instrument received face validity as the final version of the instrument emerged after corrections were effected following comments from research supervisor. The emerging instrument was then pretested on 25 bank account owners in Enugu. Using their responses, the instrument was subjected to reliability test using the Cronbach's Alpha. The result of the Cronbach's Alpha reliability statistics was 0.823 or $82 \%$, which is considered sufficiently high for social sciences research (see Hair et al, 2010).

\subsection{Sample}

The sample respondents were purposively drawn from Onitsha and Enugu cities in Anambra and Enugu states of Nigeria respectively. Enugu was chosen because it was the former capital of the eastern region of Nigeria, which 
has its residents mostly civil servants and business people. These characteristics, agreeably, must have engendered Enugu as a city with high banking culture. Onitsha was considered because it is historically known for its high commercial activities, which also have established high banking behaviour among its residents. Due to its sample size correction component, the Cochran's formula for sample size determination with respect to infinite population was adopted and a sample size of 384 emerged. Of the total of 384 copies of the questionnaire produced, half was distributed to each gender. Based on the ratio of the population of the male and female gender in Southeast Nigeria (i.e 49.9\% male and 50.1\% female); the researcher distributed 192 copies of the questionnaire to male respondents and 192 to female respondents. Of this, male respondents returned 190 copies of the questionnaire while 188 female respondents returned their copies. Hence, 378 copies of the questionnaire were returned. The returned copies of the questionnaire were carefully checked, and those with excessive missing data (10 of them) were discarded, resulting in 368 (ie, 186 male and 182 female) usable copies - thereby yielding a response rate of 96 per cent. Such a response rate was considered sufficient for statistical reliability and generalizability (Tabachnick \& Fidell, 2001) and most satisfactory, especially when compared with earlier research works on bank selection decisions (Khazeh \& Decker, 1992-93; Huu \& Karr, 2000; Gerrard \& Cunningham, 2001). This relatively high response rate was attributed to the self-administered approach undertaken in distributing copies of the questionnaire.

\subsection{Analysis}

The SPSS 16.0 programme was used for processing the primary data of this study. The responses within the various factor groups were tested for internal reliability using Cronbach's Alpha test. The Principal Component Analysis (PCA) of factor analysis, with varimax rotation, was used to reduce a large number of variates to some smaller number of groups by telling which seem to say the same thing. Hair et al $(2010$, p16) states that the objective of the PCA " is to find a way of condensing the information contained in a number of original variables into smaller set of variates (factors) with a minimal loss of information." PCA can be conducted on an unrotated or rotated basis, and if it is carried out on a rotated basis, various techniques are available. Hair et al (2010) sustained that among the various techniques, varimax tends to be the preferred one for clearer separation of the factors. The results of our factor analysis with varimax rotation are presented in Table 2.

\section{Findings}

\subsection{Demographic profile}

The first section of the questionnaire gathered information about the respondents' personal, demographic and economic characteristics as shown in Table 1.

Insert Table 1 here

\subsection{Analysis}

We use factor analysis with principal component extraction to determine the underlying factors. Table 2 below shows summary of the result of the analysis based on Varimax with Kasier Normalization as the rotation method while the rotation converged in 6 iterations. An accepted method of interpretation of factor loadings is to regard as significant any variable with factor loading of 0.40 or greater as associated with the appropriate factor (Mokhlis, 2009); hence we use a factor loading benchmark of 4.00 and any factor loading of less than 4.00 is considered insignificant. This benchmark is also posited by Hair et al $(2010$, p.118) where they noted that "although factor loadings of 0.30 to 0.40 are minimally acceptable, values greater than 0.50 are generally considered necessary for practical significance". However, following the factor loading benchmark of 0.40 , two components were considered insignificant, leaving us with 6 principal components.

Factor analysis was deemed appropriate for the items because the Keiser-Meyer-Olkin (KMO) measure of sampling adequacy test index equalled 0.756 and Bartlett's test gives a significance level of less than 0.0001 confirming the appropriateness of the factor model. The analysis yielded a 6 principal component solution, which together explained more than half of the variance observed in the variables ( 88.40 per cent), thereby satisfying the percentage of variance criterion for social science research (Hair et al. 2010).

The six factors identified are convenient location and availability of ATM, people influence, secure feeling, marketing promotion, speedy and efficient service, and financial benefits. Table 2 depicts the sorted rotated factor loadings for the items based on a six-factor extraction. The Cronbach alpha was used to measure internal reliability by unit weighting items with salient loadings in a factor where Cronbach's alpha coefficient at 0.5 or higher was considered acceptable (Kerlinger \& Lee, 2000). These factors produced alpha coefficients between 0.60 and 0.87 ; indicating high internal consistency and reliability (see Table 2 ).

Insert Table 2 here 


\subsection{Ranking of Bank Selection Criteria}

Table 3 shows the choice criteria for both male and female customers ranked in order of mean importance of each factor. Visual inspection of the table reveals that 'secure feeling' and 'speedy and efficient service' are most important in the selection decision of both male and female respondents, being in the top two criteria in each case. Male respondents ranked 'financial benefits' as a third most important factor but ranked fourth by female respondents. On the other hand, 'convenient location and availability of ATM' is ranked third by female respondents while male respondents ranked this factor as fourth. Male respondents ranked 'marketing promotion' fifth while female respondents ranked it sixth. 'People influence' ranked sixth for male respondents and ranked fifth for female respondents. Apparently, the least important selection factor for both male and female respondents are 'marketing promotion' and 'people influence'.

There are some similarities between the findings of this study and the findings of earlier studies. The identification of 'secure feeling' as most important factor in selection decision by male and female is consistent with the findings by Thwaites and Vere (1995), Almossawi (2001), Gerrard and Cunningham (2001) and Omar and Orakwue (2006). In particular, 'secure feeling' reflects respondents' desire of banking with a stable bank and assurance of confidentiality when making a transaction. They also tend to put more emphasis on 'speedy and efficient services' for both male and female respondents, which is consistent with finding of Omar and Orakwue (2006) in their Abuja study wherein they reported that this finding is reflective of an ordinary Nigerian who is typically in a hurry and want things to be done fast. Accordingly, Omar and Orakwue (2006) report: "One of the interesting findings from our study is that both male and female customers value their time highly and expect their banking transactions to be completed as quickly as possible." Although 'financial benefit' was a less important factor in the study of Omar and Orakwue (2006), it is a very important bank selection factor for male respondents in the present southeast study. The fourth most important factor for the male respondents and third most important factor for the female respondents is 'convenient location and availability of ATM'. This finding is consistent with the finding of a number of studies (for example, Narteh and Owusu-Frimpong, 2010). Omar and Orakwue's study did not consider ATM and branch network as factors since their study was carried out in a period where ATM in the Nigerian bank sector was not in use, which again has made the present study and finding germane for bank management.

Due to their low mean scores, two factors: 'marketing promotion' and 'people influence', were considered least important bank selection criteria for both male and female respondents. The two least important factors in selecting a bank for both male and female respondents - 'marketing promotion' and 'people influences'- yet again, are reflective of the results of Gerrard and Cunningham (2001). The low position of the factor 'people influences' (ranked sixth for male and fifth for female respondents) is also consistent with the results of Almossawi (2001), Huu and Karr (2000) and Cicic et al. (2004). This finding may be explained by the fact that southeast Nigerians possesses a greater self-confidence and therefore prefer to act independently during the selection process rather than relying on the recommendations and experiences of others, which shows that influence of friends and relatives in bank selection is declining in recent times. However, in the present study, female respondents ranked 'people influence' above 'marketing promotion', which corroborates the Abuja study of Omar and Orakwue (2006) that "female customers tend to rely on recommended banks because they feel friends or relatives who have recommended the bank have good banking experiences with the recommended bank."

\subsection{Differences in Bank Choice Criteria by Gender}

Z-test was used to test the statistical differences between the means for each of the selection factors between male and female. In such an approach, the null hypothesis that there is no difference in means between groups is rejected if the z-statistic is sufficiently large to be significant. The probability level accepted for statistical significance of $z$-statistic in the present study was set at $p<0.1, p<0.01$, and $p<0.05$ respectively, showing there was $10 \%, 1 \%$, and $5 \%$ probability that the result occurred by chance. Table 4 presents the results.

There were statistically significant differences between male and female bank customers on certain attributes. At the 0.1 level, factor of which both samples had variation is 'financial benefit' $(z=-1.940, p=0.053)$, with male having a higher mean than female respondents. The import of this is that male respondents will be influenced more by financial benefits than the female respondents. Hence, targeting male customers requires emphasis on financial benefits such as overdraft/loan facilities, low interest charge, zero COT, etc. At the 0.05 significant level, there was variation for factor 'people influence' $(\mathrm{z}=2.198, \mathrm{p}=0.028)$, indicating that female respondents have high mean scores than the male. This is further reflective of the fact that female customers place high reliance on family, friends, and colleagues influence in their bank selection decision. At the 0.1 level, factors of 
which both samples had variation were 'convenient location and availability of ATM' $(z=2.835, p=0.005)$ and 'marketing promotion' $(\mathrm{z}=-2.604,0.010)$. Female respondents had higher mean values for 'convenient location and availability of ATM' than male respondents. Male respondents, on the other hand, had higher mean values for 'marketing promotion' than their female counterparts.

It is worthy of note that no statistical difference is found for both samples of male and female respondents with respect to 'secure feelings' and 'speedy and efficient service' at $0.1,0.05$, and 0.01 levels of significance. Hence targeting both genders using same promos with high content of 'secure feeling' and 'speedy and efficient service' message will make promotional sense with less promotional cost. Accordingly, at level $\mathrm{p}<0.05$ and $\mathrm{p}<0.01$, there was no statistical difference between male and female respondents with respect to 'financial benefit'. At $\mathrm{p}<0.1$ and $\mathrm{p}<0.05$, factors 'convenient location and ATM' and 'marketing promotion' did not show any statistical difference for both male and female respondents. At $\mathrm{p}<0.1$ and $\mathrm{p}<0.01$ respectively, both respondents did not show any statistical difference to 'people influence'.

\section{Discussion}

As shown in Table 4, the first most important factor is 'secure feeling'. Arguably, the reason for this is that in recent times, particularly before the bank consolidation era, the Nigerian banking sector has been characterised by bank failures. As a result, most Nigerians (including southeast Nigerians) could not recover their funds. This resulted in widespread fear and loss of confidence in the banks. Though since the year 2005, banks in Nigeria have recapitalized to 25 billion Naira minimum paid-up share capital, yet evidence of financial stability (a component of 'secure feeling') continue to be a strong parameter for bank selection for southeast Nigerians in the post-consolidation era. Granted, most bank customers may not possess the skill to analyse financial statements to determine financial stability of banks by computing the liquidity and stability ratios, but the reliance on Central Bank of Nigeria's (CBN) pronouncement in this regard is common. Thus in the event of CBN or any other reliable third party making adverse pronouncement in this regard about a bank's financial stability could trigger bank massive switch and reselection behaviour among bank customers using this basis. This finding corroborates the finding of some study (such as Gerard and Cunningham, 2001; Thwaites and Vere, 1995; Almossawi, 2001 and Mokhlis, 2009) wherein "secure feeling" was found to be the most important bank selection criteria in Singapore; Narteh and Owusu-Frimpong (2010) in Ghana and Omar and Orakwue (2006) the Abuja study. Both male and female segments place utmost value on banks that possess the measures of 'secure feelings', including confidentiality, financial stability, safety of funds, bank's reputation, and bank size.

As evidenced by table 3, 'speedy and efficient service' is also a very germane bank selection factor for both samples. This corroborates findings of earlier studies (for example, Yue and Tom, 1995; Coyle, 1999; Kaynak et al, 1991; and Omar and Orakwue, 2006). Consistent with finding of Omar and Orakwue (2006) in their Abuja study, this finding is reflective of an ordinary Nigerian who is typically in a hurry and want things to be done fast.

\section{Managerial Implication, Conclusion, Limitations, and Recommendation for Future Research}

\subsection{Managerial Implication}

The results of this study provide some significant guidance for bank marketers in relation to crafting marketing strategy specifically aimed at attracting the male or female bank customer segments. The main focus of their campaigns should be on emphasising their bank's financial stability; hence, reposing confidence in the segment that their funds are secure and customers can have their funds whenever they want it. To do this, the banks should maintain high capital and liquidity ratios.

Similarly, the traditional belief in Nigeria about gender equity is in decline. The results of this study suggest that gender discrimination is no longer relevant. Bank managers must therefore take into consideration the changing environment when developing financial service marketing strategies. The needs and wants of female customers must also be considered in the development of retail banks' service marketing plans.

Hence, to capture the female segment, bank marketers should emphasise branch networks and widespread functional ATMs as well as the use of third party endorsements in their promos since people influence play a key role in the bank selection process of the female segment. On the other hand, to attract the male gender segment, banks should emphasise financial benefits, convenient locations and functional ATMs and powerful marketing promotions. People influence or third party endorsements play little role in motivating the male segment. For both genders, secure feeling and speedy and efficient service are critical in bank selection.

\subsection{Conclusion}

The significant differences noted in the four factors are clear indications that time is ripe for bank management 
to start considering male and female segments as distinct market segments. The traditional practice has been that men are generally considered the bread winner and main financial decision-maker of the family; but the result of this study indicates that this situation is changing. The fact that the bank selection criteria of the male gender differs with that of female gender suggest that treating the two as distinct market segments is imperative, considering also the increasing earning power and independent financial-decision making power of the female gender. The management of banks in Nigeria must acknowledge that it may not longer make business sense to continue to design a single marketing strategy and campaign for both segments. They have to treat the female segment as a distinct market segments, as the bank market is heterogeneous. As the key characteristics in consumer groups differ slightly, it is important for banks to target market segments that are homogenous in terms of relevant financial service purchase behaviour. The women's market in Nigeria is the likely growing segment as a result of more women acquiring formal education; taking up paid employment; and occupying key positions both in corporate and government establishments. Now, most men allow their wives to get paid employment away from the home; and more women now solely decide how use their own income. Increasingly, women are becoming powerful income earners and independently decide on how to use a large part of their incomes (see NDHS, 2008).

\subsection{Limitations}

This study was beset by a number of limitations, which could be the basis and direction for future research. First, the sample size of this study was drawn only from Onitsha and Enugu, two cities from two states (Anambra and Enugu). Since there are five states that constitute the southeast zone of Nigeria, the use of two states undermines the claim that the study covers southeast Nigerian entirely because the sample size did not include respondents from the other three states. Second, the previous bank marketing strategies have been based on research results pertaining to men because those studies were not gender-based. Since the female gender is the key consideration of this study, it is logical to have more female in the sample size for a deeper insight and reliable result. Third, a study of this nature should incorporate a focused group discussion of selected bank marketing staff in other to further enrich the empirical value and precision of its findings.

\subsection{Recommendations for future research.}

The foregoing shortcomings of this study uncover potential grounds for future research. For instance, a robust southeast Nigerian study should draw sample respondents from the six states of the southeast; should include more number of the female gender; and should incorporate focused group discussions from bank marketing staff. In addition, since the southeast Nigerians are predominantly Christians, a similar study on the analysis of the influence of gender on the choice of banks in Northcentral Nigeria, predominantly populated Muslims, will be thoughtful. Also, a comparative study between the Christian and Muslim gender on the choice of banks in Nigeria will reveal gender-based differences in bank choice determinants between Christians and Muslims in Nigeria so that banks will gain insight on how best to target these groups in their context.

\section{Acknowledgement}

The authors wish to appreciate Dr. I. C. Nwaizugbu, an Associate Professor of Marketing at the Nnamdi Azikiwe University, for his guide and insightful comments from the commencement of this study to the end. In addition, we appreciate Mr. Kene Nnwamefor for time spared for proofreading the final work; as well as the two anonymous reviewers for their useful insights and comments towards improving upon the initial manuscript submitted.

\section{References}

Agu, C. C. (1992). Analysis of the determinants of the Nigerian banking system's profits and profitability performance. Journal of Savings and Development, 16(1), 353-370.

Albert, M., Njanike, K., and Mukucha, P. (2011). Gender Effects on Customer Satisfaction in Banking Industry: a case of commercial banks in Bindura, Zimbabwe. E3 Journal of Business Management and Economics, 2(1). Pp. 40-44.

Almossawi, M. (2001). Bank selection criteria employed by college students in Bahrain: an empirical analysis. International Journal of Bank Marketing, 19(3), 115-125. http://dx.doi.org/10.1108/02652320110388540

Alsop, R. (1984). Firms try to tap growing over-50 population. The Wall Street Journal, 23 (August), 21.

Amin, H. (2008). Choice criteria for Islamic home financing: empirical investigation among Malaysian bank customers. International Journal of Housing Markets and Analysis, 1(3), 256-274. http://dx.doi.org/10.1108/17538270810895105 
Anderson, W.T., Fox, E.P., \& Fulcher, D.G. (1976). Bank selection decision and market segmentation. Journal of Marketing, 40 (1), 40-45. http://dx.doi.org/10.2307/1250674

Boyd, W. L., Leonard, M., \& White, C. (1994). Customer preferences for financial services: An analysis. International Journal of Bank Marketing, 12(1), 9-15. http://dx.doi.org/10.1108/02652329410049562

Cicic, M., Brkic, N., \& Agic, E. (2004). Bank selection criteria employed by students in a southeastern European country: An empirical analysis of potential market segments preferences. In J. Wiley \& P. Thirkell (Eds.), Marketing accountabilities and responsibilities: Proceedings of the ANZMAC 2004 Conference, Wellington, 29 November-1 December 2004. Australian \& New Zealand Marketing Academy.

Coyle, T. (1999). The bank of tomorrow. American's Community Banker, 8(7), 16-18.

Delvin, J. F. (2002). An analysis of choice criteria in the home loans market. International Journal of Bank Marketing, 20(5), 212-226. http://dx.doi.org/10.1108/02652320210437661

Edris, T. A., \& Almahmeed, M. A. (1997). Services considered important to business customers and determinants of bank selection in Kuwait: a segmentation analysis. International Journal of Bank Marketing, 15(4), 126-133. http://dx.doi.org/10.1108/02652329710189393

Erol, C., Kaynak, E., and El-Bdour, R. (1990). Conventional and Islamic banks: patronage behaviour of Jordanian customers. International Journal of Bank Marketing, Vol. 8 No. 4, pp. 25-35. http://dx.doi.org/10.1108/02652329010004231

Fitts R.L. (1975). "Predictors of usage rates for selected commercial bank services: a crosssectional approach utilizing socioeconomic, demographic and attitudinal variables", unpublished doctoral dissertation, University of Alabama.

Ford, J., \& Jones, A. (2001). Choosing a mortgage: a research review. Consumer Research Paper, Number 8, London.

Gerrard, P., \& Cunningham, J. B. (2001). Singapore's undergraduates: how they choose which bank to patronize. International Journal of Bank Marketing, 19 (3), 104-114. http://dx.doi.org/10.1108/02652320110388531

Gerrard, P., \& Cunningham, J.B. (1997). Islamic banking: a study in Singapore. International Journal of Bank Marketing, 15(6), 204-216. http://dx.doi.org/10.1108/02652329710184433

Gray, A.D. (1977). Student attitudes toward banking. Unpublished BSc dissertation, University of Strathclyde.

Hair, J. F., Black, W. C., Babin, B. J., \& Anderson, R. E. (2010). Multivariate Data Analysis (7 $7^{\text {th }}$ ed.). New Jersey: Prentice Hall Inc.

Haron, S., Ahmed, N., \& Planisek, S. (1994). Bank patronage factors of Muslim and non-Muslim customers. International Journal of Bank Marketing, 12(1), 32-40. http://dx.doi.org/10.1108/02652329410049599

Hinson, R., Dasah, J., Owusu-Frimpong, N., \& Kodua, P. (2010). Undergraduate first time bank customers' perception of service quality in Ghana. Proceedings of the $11^{\text {th }}$ Annual Conference of the International Academy of African Business and Development [IAABD], May 2010, University of Lagos, Nigeria, pp. 579-587.

Hinson, R., Owusu-Frimpong, N., \& Dash, J. (2009). Key motivations for bank patronage in Ghana. International Journal of Bank Marketing, 27(5), 381-399. http://dx.doi.org/10.1108/02652320910979898

Hisrich, R. D., \& Ozturk, S.A. (1999). Women entrepreneur in a developing economy. Journal of Management Development, 18 (2), 114-124. http://dx.doi.org/10.1108/02621719910257639

Holstius, K., and Kaynak, E. (1995). Retail banking in Nordic countries: the case of Finland. International Journal of Bank Marketing, Vol. 13 No. 8, pp. 10-20. http://dx.doi.org/10.1108/02652329510098873

Huu, P.T., \& Kar, Y.H. (2000). A study of bank selection decisions in Singapore using the analytical hierarchy process. International Journal of Bank Marketing, 18(4), 170-80. http://dx.doi.org/10.1108/02652320010349058

Javalgi, R. G., Armaco, R. L., \& Hoseini, J. C. (1989). Using the analytical hierarchy process for bank management: Analysis of consumer selections decisions. Journal of Business Research, 19(1), 33-49. http://dx.doi.org/10.1016/0148-2963(89)90039-8

Jibril, M., Teferra, D., \& Altbach, P. G. (2003). African higher education: An international reference handbook. Bloomington: Indiana University Press.

Joint Admission and Matriculation Board (JAMB) (2009). Unified Tertiary Matriculation Examination Brochure. Abuja: Joint Admission and Matriculation Board Press. 
Kaynak, E., \& Kucukemiroglu, O. (1992). Bank and product selection: Hong Kong. International Journal of Bank Marketing, 10(1), 3-16. http://dx.doi.org/10.1108/02652329210007858

Kaynak, E., Kucukemiroglu, O., \& Odabasi, Y. (1991). Commercial bank selection in Turkey. International Journal of Bank Marketing, 9(4), pp. 30-9. http://dx.doi.org/10.1108/02652329110004249

Kazeh, K., \& Decker, W. (1993). How customers choose banks. Journal of Retail Banking, XIV(4), Winter, 92-93.

Kerlinger, F. M., \& Lee, H. (2000). Foundations of behaviorial research. ( $4^{\text {th }}$ edition). Stamford: Wadsworth.

Laroche, M., Rosenblatt, J.A., \& Manning, T. (1986). Services used and factors considered important in selecting a bank: an investigation across diverse demographic segments. International Journal of Bank Marketing, 4(1), 35-55. http://dx.doi.org/10.1108/eb010771

Lewis, B.R. (1982). Student accounts: a profitable segment? European Journal of Marketing, 16(3), 63-72. http://dx.doi.org/10.1108/EUM0000000004839

Ma, K.Y., Ng, B.K., \& Teo, C.S. (1996). Bank selection criteria and the practice of multiple banking among degree holders in Singapore. Unpublished BBus dissertation, Nanyang Technological University, Singapore.

Martenson, R. (2007). Consumer choice criteria in retail bank selection. International Journal of Bank Marketing, Vol.3 No.2, pp.64-74. http://dx.doi.org/10.1108/eb010755

Mason, J.B., and Mayer, M.L. (1974). Differences between high-and-low-income savings and checking account customers. The Magazine of Bank Administration, Vol. 65, June, pp. 48-52.

Meyers-Levy, J., \& Sternthal, B. (1991). Gender differences in the use of message cues and judgements. Journal of Marketing Research, 28 (1), 84-96. http://dx.doi.org/10.2307/3172728

Mokhlis, S. (2009). Determinants of choice criteria in Malaysia's retail banking: an analysis of gender-based choice decisions. European Journal of Economics, Finance and Administrative Science, Issue 16, 18-30.

Mokhlis, S., Mat, N. H. N., and Salleh, H. S. (2010). Ethnicity and Choice Criteria in Retail Banking: A Malaysian Perspective. International Journal of Business and Management, 5 (6), 98-104.

Muldoon, K. (1989). Are planners neglecting professional women? Personal Financial Planning, July - August, 34-37.

Nateh, B., \& Frimpong-Owusu, N. (2010, May 17-21). Customer knowledge and choice criteria in retail banking in Ghana. Paper presented at the $11^{\text {th }}$ Annual Conference of the International Academy of African Business and Development [IAABD], University of Lagos, Nigeria. 544-550.

Nigerian Demographic and Health Survey, 2008

Nkamnebe, A. D., \& Ukenna, S. (2010, May 17-21). Determinants of bank loyalty among student customers in Nigeria, Paper presented at the $11^{\text {th }}$ Annual Conference of the International Academy of African Business and Development [IAABD], University of Lagos, Nigeria, 572-578.

Nkamnebe, A. D., \& Ukenna, S. (2011, May 17-21). Factors Influencing Bank Choice among Undergraduates in Nigeria, Paper presented at the $12^{\text {th }}$ Annual Conference of the International Academy of African Business and Development [IAABD], Athabasca University, Canada, 585-593.

Omar, O and Orakwe. (2006). Determinants of retail banking choice in Nigeria: A focus on gender-based choice decisions. Journal of Business and Retail Management Research, 6(2), 67-78.

Omar, O. E. (2008). Determinants of retail bank choice in Nigeria: A focus on gender-based choice decisions. Service Business, 2(3), 249-265. http://dx.doi.org/10.1007/s11628-008-0039-1

Pass, M. W. (2006). Western US college students: Banking preferences and marketplace performance. Journal of Financial Services Marketing, 11(1), 49-63. http://dx.doi.org/10.1057/palgrave.fsm.4760016

Philip, R. P., Haynes P. J., \& Helms, M.M. (1992). Financial service strategies: Neglected niches. International Journal of Bank Marketing, 10(2), 25-28. http://dx.doi.org/10.1108/02652329210012131

Poh, B.L. (1996). Tertiary level students in Singapore and their banking relationships. Unpublished MBA dissertation, Nanyang Technological University, Singapore.

Reed, J.D. (1972). Commercial bank selection: a study in consumer decision-making. Unpublished doctoral dissertation, University of Cincinnati, Cincinnati, $\mathrm{OH}$.

Riggall, J. (1980). A new study: how newcomers select banks. ABA Journal, July, pp. 93-4. 
Srivatsa, H. S., \& Srinivasan, R. (2008). Gender based banking psychographics: An Indian empirical study. International Journal of Business Research, 8(4), 88-95.

Sudin, H, Norafifah, A., \& Planisek, S.L. (1994). Bank patronage factors of Muslim and non-Muslim customers. International Journal of Bank Marketing, 12(1), 32-40. http://dx.doi.org/10.1108/02652329410049599

Tabachnick, B. G., \& Fidell, L.S. (1996). Using multivariate statistics. New York: Harper Collins.

Tan, C.T., and Chua, C. (1986), Intention, attitude and social influence in bank selection: a study in an oriental culture. International Journal of Bank Marketing, 4(3), 43-53. http://dx.doi.org/10.1108/eb010783

Thwaites, D., \& Vere, L. (1995). Bank selection criteria: students perspective. Journal of Marketing Management, 11(3), 133-49. http://dx.doi.org/10.1080/0267257X.1995.9964334

Thwaites, D., Brooksbank, R., \& Hanson, A. (1997). Bank selection criteria in New Zealand: A student perspective. New Zealand Journal of Business, 19 (1\&2), 95-107.

Woodward, D., \& Ozbiligin, M.F. (1999). Sex equality in the financial services sector in Turkey and the UK. Women in Management Review, 14(8), 325-332. http://dx.doi.org/10.1108/09649429910301698

Yue, H., and Tom, G. (1995). How the Chinese select their banks. Journal of Retail Banking, Vol. XVI No. 4, Winter.

Table 1. Characteristics of respondents

\begin{tabular}{|c|c|c|c|c|}
\hline & \multicolumn{2}{|c|}{ Male } & \multicolumn{2}{|c|}{ Female } \\
\hline & $N=186$ & $\%$ & $\mathrm{~N}=182$ & $\%$ \\
\hline \multicolumn{5}{|l|}{ Age Group } \\
\hline$<20$ years & 3 & 1.5 & 8 & 4.5 \\
\hline $21-30$ & 57 & 30.3 & 79 & 43.4 \\
\hline $31-40$ & 74 & 39.9 & 50 & 27.2 \\
\hline $41-50$ & 22 & 11.8 & 32 & 17.7 \\
\hline $51>$ & 30 & 16.5 & 13 & 7.2 \\
\hline \multicolumn{5}{|l|}{ Level of Education } \\
\hline No education & Nil & Nil & 4 & 2.3 \\
\hline Primary school & 3 & 1.6 & 17 & 9.3 \\
\hline Secondary school & 74 & 39.8 & 59 & 32.4 \\
\hline University / college & 83 & 44.6 & 82 & 44.9 \\
\hline Professional training & 26 & 14.0 & 20 & 11.1 \\
\hline \multicolumn{5}{|l|}{ Type of Employment } \\
\hline Self-employed & 62 & 33.6 & 48 & 26.4 \\
\hline Private employer & 42 & 22.7 & 56 & 30.5 \\
\hline Public employer & 82 & 43.7 & 78 & 43.1 \\
\hline \multicolumn{5}{|l|}{ Occupation } \\
\hline Armed forces / police & 32 & 17.1 & 2 & 2.5 \\
\hline Farming & 26 & 13.8 & 8 & 8.1 \\
\hline Trading / retailing & 41 & 22.3 & 31 & 40.1 \\
\hline Clerical / sales / nursing & 55 & 29.8 & 26 & 43.5 \\
\hline Managerial/ professional & 32 & 17.0 & 5 & 5.8 \\
\hline
\end{tabular}

Source: Field survey, 2011 
Table 2. Factor groups of bank choice criteria

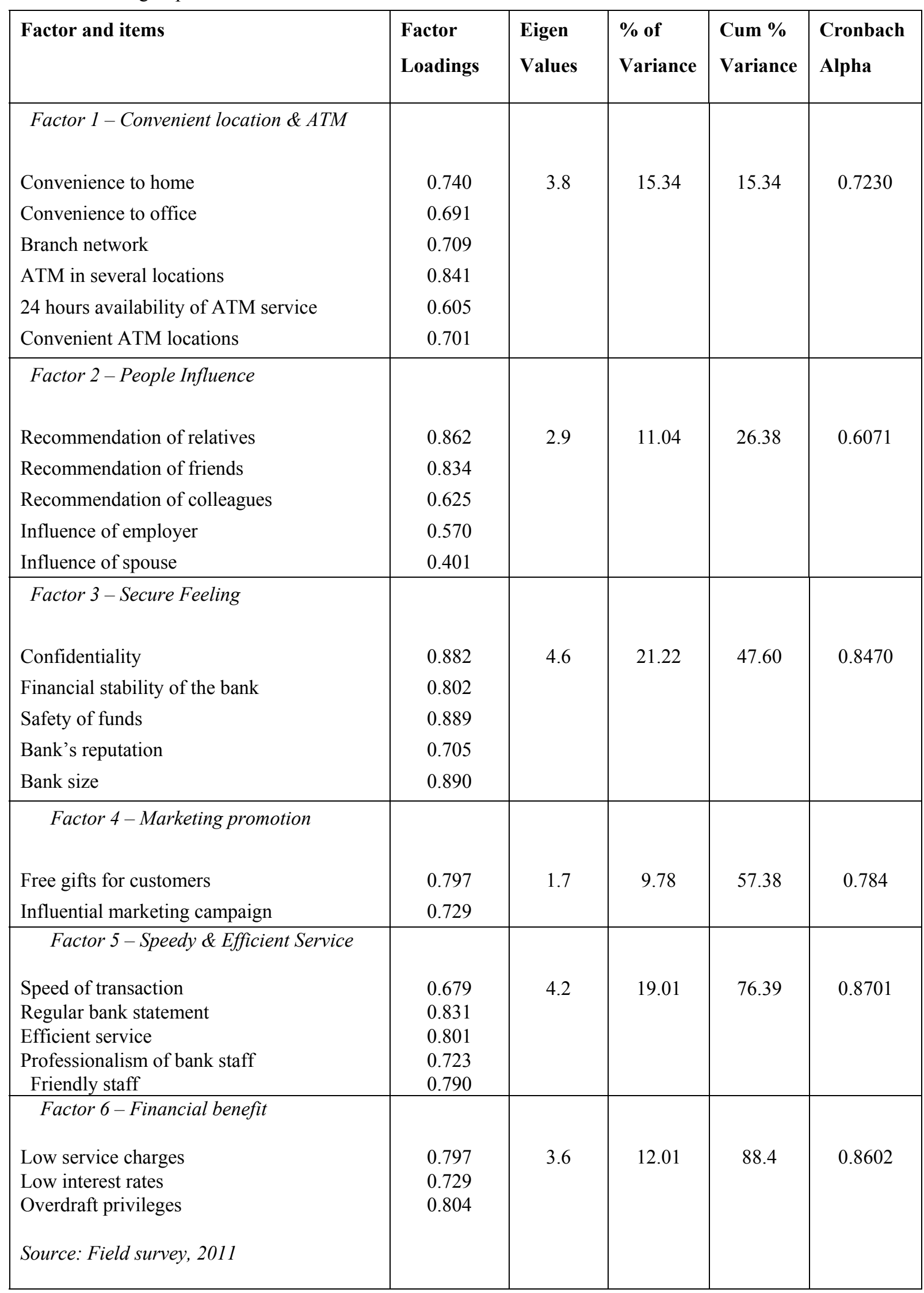


Table 3. Ranking importance of bank selection factors by gender

\begin{tabular}{|l|l|l|c|c|}
\hline \multirow{2}{*}{ Selection factor } & \multicolumn{3}{l|}{ Male $(\mathbf{n}=\mathbf{1 8 6})$} & \multicolumn{2}{l|}{ Female (n= 182) } \\
\cline { 2 - 5 } & Mean & Rank & Mean & Rank \\
\hline Secure feeling & 4.847 & 1 & 4.787 & 1 \\
Speedy and efficient service & 4.711 & 2 & 4.688 & 2 \\
Financial benefit & 4.548 & 3 & 4.501 & 4 \\
Convenient location and availability of ATM & 4.381 & 4 & 4.570 & 3 \\
Marketing promotion & 3.159 & 5 & 3.101 & 6 \\
People influence & 3.104 & 6 & 3.485 & 5 \\
\hline Based on a five-point Likert scale 1 = not important at all; 5 = very important \\
Source: Field Survey, 2011
\end{tabular}

Table 4. Differences in bank selection criteria by gender

\begin{tabular}{|c|c|c|c|c|}
\hline Selection factor & Mean & S.D. & Z-statistics & Sig. \\
\hline \multicolumn{5}{|l|}{ Secure feeling } \\
\hline $\begin{array}{l}\text { Male } \\
\text { Female }\end{array}$ & $\begin{array}{l}4.847 \\
4.787\end{array}$ & $\begin{array}{l}0.517 \\
0.693\end{array}$ & -1.445 & 0.152 \\
\hline \multicolumn{5}{|c|}{ Speedy and efficient service } \\
\hline $\begin{array}{l}\text { Male } \\
\text { Female }\end{array}$ & $\begin{array}{l}4.711 \\
4.688\end{array}$ & $\begin{array}{l}0.633 \\
0.584\end{array}$ & 0.688 & 0.492 \\
\hline \multicolumn{5}{|l|}{ Financial benefit } \\
\hline $\begin{array}{l}\text { Male } \\
\text { Female }\end{array}$ & $\begin{array}{l}4.548 \\
4.501 \\
\end{array}$ & $\begin{array}{l}0.789 \\
0.755\end{array}$ & -1.940 & $0.053^{*}$ \\
\hline \multicolumn{5}{|c|}{ Convenient location \& ATM } \\
\hline $\begin{array}{l}\text { Male } \\
\text { Female }\end{array}$ & $\begin{array}{l}4.381 \\
4.570 \\
\end{array}$ & $\begin{array}{l}0.571 \\
0.489 \\
\end{array}$ & 2.835 & $0.005 * * *$ \\
\hline \multicolumn{5}{|c|}{ Marketing promotion } \\
\hline $\begin{array}{l}\text { Male } \\
\text { Female }\end{array}$ & $\begin{array}{l}3.159 \\
3.101\end{array}$ & $\begin{array}{l}0.879 \\
0.781\end{array}$ & -2.604 & $0.010^{* * *}$ \\
\hline \multicolumn{5}{|l|}{ People influence } \\
\hline $\begin{array}{l}\text { Male } \\
\text { Female }\end{array}$ & $\begin{array}{l}3.104 \\
3.485\end{array}$ & $\begin{array}{l}0.784 \\
0.598\end{array}$ & 2.198 & $0.028^{* *}$ \\
\hline
\end{tabular}

